\title{
Validity and reliability of the Turkish version of the Patient Health Questionnaire-8 for patients with systemic sclerosis
}

\author{
Hasta Sağlığı Anketi-8’in Türkçe versiyonunun sistemik sklerozlu hastalar için geçerlik ve güvenilirliği
}

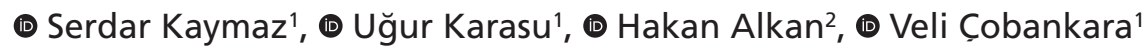 \\ 1 Pamukkale University Faculty of Medicine, Department of Rheumatology, Denizli, Turkey \\ 2Pamukkale University Faculty of Medicine, Department of Physical Medicine and Rehabilitation, Denizli, Turkey
}

\begin{abstract}
Objective: Depressive symptoms harm the quality of life, with a higher prevalence in patients with rheumatological diseases. The Patient Health Questionnaire-9 (PHQ-9) used for depression evaluation in patients with systemic sclerosis (SSC) has been validated in Turkish. However, the Turkish version of PHQ-8, a shorter form of PHQ-9, has not been validated. This study aimed to evaluate the reliability and validity of PHQ-8 in Turkish patients with SSC.

Methods: Permission was obtained from the authors who developed the original scale. The testing procedure for translation and cultural adaptation was carried out according to the following steps: preparation, forward translation, reconciliation, back-translation/backtranslation review, harmonization, finalization, and proofreading. Patients' demographic parameters, comorbidities, education levels, organ involvement, Health Assessment Questionnaire (HAQ), Scleroderma Health Assessment Questionnaire (SHAQ), Short form36 (SF-36), and Multidimensional Assessment of Fatigue (MAF) results were recorded. Construct validity, test-retest reliability, and internal consistency were evaluated in 43 patients with SSC.

Results: Despite some linguistic changes, the questionnaire had satisfactory content validity. There were moderate-to-strong correlations between the Turkish version of PHQ-8 and SHAQ consisting of visual analog scale ( $r s=0.6$ to 0.7$)$ and HAQ disability ( $r s=0.5)$, the subscales of SF-36 ( $r s=0.6$ to 0.8$)$, and MAF ( $r s=0.7)$. The internal consistency (Cronbach's alpha) of the questionnaire was 0.98 , with corrected item-to-total correlations of $>0.40$, and an intraclass correlation coefficient of 0.947 for the total score (Intraclass correlation coefficient $=0.947,95 \%$ confidence interval, 0.817-0.985).

Conclusion: The Turkish version of PHQ-8 could be used to evaluate patients with SSC with satisfactory construct validity and sufficient reliability.
\end{abstract}

Keywords: Depression, quality of life, SSC

\section{Öz}

Amaç: Depresif belirtiler yașam kalitesine zarar verir ve romatolojik hastalığı olan hastalarda daha sık görülür. Sistemik sklerozlu (SSC) hastalarda depresyon değerlendirmesi için kullanılan Hasta Sağlığı Anketi-9'un (PHQ-9) Türkçe validasyonu yapılmıștır. Ancak, PHQ-9'un daha kısa bir formu olan PHQ-8'in Türkçe versiyonu doğrulanmamıștır. Bu çalıșmada, SSc'li Türk hastalarda $\mathrm{PHQ}-8$ 'in güvenilirliğinin ve geçerliliğinin değerlendirilmesi amaçlandı.

Yöntem: Orijinal ölçeği geliștiren yazarlardan izin alınmıștır. Ceviri ve kültürel adaptasyon için test prosedürü șu adımlara göre gerçekleștirilmiștir: Hazırlık, ileri çeviri, mutabakat, geri çeviri/geri çeviri incelemesi, uyumlaștırma, sonuçlandırma ve düzeltme okumasıdır. Hastaların demografik parametreleri, komorbiditeleri, eğitim düzeyleri, organ tutulumu, Sağlık Değerlendirme Anketi (HAQ), Skleroderma Sağlık Değerlendirme Anketi (SHAQ), Kısa form-36 (SF-36) ve Cok Boyutlu Yorgunluk Değerlendirmesi (MAF) sonuçları kaydedildi. SSc'li 43 hastada geçerlilik, test-tekrar test güvenilirliği ve iç tutarlılık değerlendirildi.

Bulgular: Bazı dilsel değișikliklere rağmen, anket tatmin edici bir içerik geçerliliğine sahipti. PHQ-8'in Türkçe versiyonu ile SF-36'nın alt ölçekleri $(r s=0,6-0,8), \operatorname{MAF}(r s=0,7)$ ve HAQ skalasının alt komponentleri olan özürlülük $(r s=0,5)$ ve görsel analog ölçeği $(r s=0,6-0,7)$ arasında ortagüçlü bir korelasyon mevcuttu. Anketin iç tutarlılığı (Cronbach's alfa) 0,98, düzeltilmis madde-toplam korelasyonları $>0,40$ ve toplam puan için 0,947 sınıf içi korelasyon katsayısı (sınıf içi korelasyon katsayısı=0,947, \%95 güven aralığı, 0,817-0,985) idi.

Sonuç: PHQ-8'in Türkçe versiyonu, tatmin edici geçerlilik ve yeterli güvenilirlik ile SSc'li hastaları değerlendirmek için kullanılabilir.

Anahtar Kelimeler: Depresyon, yașam kalitesi, SSc

\section{Iletișim / Correspondence:}

Serdar Kaymaz MD, Pamukkale University Faculty of Medicine, Department of Rheumatology, Denizli, Turkey

Tel.: +90 5538720626 E-posta: dr.serdarkymaz@gmail.com ORCID ID: orcid.org/0000-0002-6958-5436

Geliș Tarihi / Received: 24.06.2021 Kabul Tarihi / Accepted: 13.08.2021

Atıf / Cite this article as: Kaymaz S, Karasu U, Alkan H, Cobankara V. Validity and reliability of the Turkish version of the Patient Health Questionnaire-8 for patients with systemic sclerosis. Ulus Romatol Derg 2021;13(2):66-72

๑Telif Hakkı 2021 Türkiye Romatoloji Derneği / Ulusal Romatoloji Dergisi, Galenos Yayınevi tarafından yayınlanmıștır.

${ }^{\odot}$ Copyright 2021 by the Turkish Society for Rheumatology / Journal of Turkish Society for Rheumatology published by Galenos Publishing House. 


\section{Introduction}

Systemic sclerosis (SSc) is a multisystemic autoimmune inflammatory disease. The disease is characterized by the deposition of collagen and matrix molecules in the skin and internal organs. ${ }^{[1]}$ It is more common in women than in men. ${ }^{[2]}$ It has various clinical presentations ranging from limited skin thickening to severe organ involvement such as pulmonary fibrosis or pulmonary hypertension. SSc is classified into two subtypes based on the extent of skin involvement: limited cutaneous SSc (lcSSc) and diffuse cutaneous SSc (dcSSc). ${ }^{[1]}$ Currently, there is no specific cure for SSc to reverse its effects; therefore, the aim of treatments is to limit the symptoms of the disease and to improve health-related quality of life (HRQL). ${ }^{[3]}$

Compared with other rheumatic diseases, patients with SSc experience depression more commonly. ${ }^{[4,5]}$ About one to two-thirds of patients with SSc exhibit the symptoms of depression. ${ }^{[6,7]}$ Symptoms including digital ulcer, reflux, pain, constipation, fatigue, dyspnea, and physical changes are considered negative and specific symptoms of the disease. ${ }^{[4]}$ Depression, one of the negative symptoms, deteriorates the quality of life of patients. ${ }^{[8]}$ Moreover, it causes patients to be less active in activities of daily life, to have lower self-efficacy, and to adopt health-enhancing behaviors less frequently. ${ }^{[9]}$

Depressive symptoms have an important role in identifying and addressing the patients with SSc. Depressive symptoms of patients can be identified using patientreported outcome measures (PROMs). ${ }^{[10]}$ An example of such PROMs is the Patient Health Questionnaire-9 (PHQ9), which is considered a valid and reliable instrument for evaluating SSc. ${ }^{[1,12]}$ The PHQ-9 is a brief well-validated measure for detecting and monitoring depression. ${ }^{[13]}$ The Patient Health Questionnaire-8 (PHQ-8) is a shorter form of PHQ-9 without item 9 of the original questionnaire about thoughts of self-harm and death. ${ }^{[13]}$ This test is used to identify depression symptoms, facilitate communication, support self-management of patients, and refer patients to appropriate healthcare providers. ${ }^{[14]}$ Furthermore, the use of PHQ-8 is recommended because of the presence of a high correlation between PHQ-9 and PHQ-8. ${ }^{[15]}$

PHQ-9 has been previously validated in several languages, including Turkish. Two studies conducted in Switzerland emphasized the reliability and validity of PHQ9. ${ }^{[16,17]}$ The Turkish version of PHQ-9 has been found to be reliable for Turkish immigrants living in Germany. ${ }^{[18]}$ PHQ8 has also been shown to be valid in Swedish SSc patients. ${ }^{[19]}$ However, there is no Turkish validation study of this test in the literature. This study aimed to evaluate the reliability and validity of PHQ-8 in Turkish patients with SSc.

\section{Materials and Methods}

Study participants were recruited from a rheumatology center in Turkey. The study included patients over the age of 18 years, diagnosed with SSc according to the 2013 American College of Rheumatology/European League Against Rheumatism criteria, with a disease duration of at least 1 year, who fluently spoke and understood Turkish. ${ }^{[20]}$ Forty-three patients with SSc who were followed up in our center and who met the study criteria were included to evaluate construct validity, internal consistency, and testretest reliability of the questionnaire. ${ }^{[2]}$ No difference has been reported between 2 days and 2 weeks for test-retest reliability. ${ }^{[22]}$ Therefore, all subjects were re-evaluated after 2 days. They were stable in the interim period. On the second examination, PHQ-8 was administered to assess the time stability of the measurements. The approval for the study was obtained from the local ethics committee (numbered 10.150.1.90, date: 25.02.2021).

\section{Patient-Reported Outcome Measures (PROM)}

Patient Health Questionnaire (PHQ-8): It measures the frequency of depressive symptoms over the past two weeks. Each item has options scored between 0 and 3. The total score is calculated by summing the scores obtained from each item and ranges between 0 and 24. A score of 0-4 represents the absence of any significant depressive symptoms, 5-9 mild depressive symptoms, 10-14 moderate depressive symptoms, 15-19 moderately severe depressive symptoms, and 20-24 severe depressive symptoms. ${ }^{[13]}$ It is asked to those showing any problems in their responses to determine to what extent patients had difficulty in different domains of everyday life due to these problems. In our study, the options of the relevant item were scored between 0 and 3 using the statements of not difficult at all (0), somewhat difficult (1), very difficult (2), and extremely difficult (3). In our study, the final item was used for evaluating any changes that patients had during the test-retest interval.

Health Assessment Questionnaire (HAQ): It is used for evaluating pain, disability, and interferences of the disease with activities of daily living. ${ }^{[23]}$ It includes the HAQ-Disability Index (HAQ-DI) and visual analog scale (VAS). HAQ-DI comprises 20 items to assess activities of daily living, with a total score ranging from 0 (no disability) to 3 (severe disability). VAS is used to assess pain on a $15 \mathrm{~cm}$ straight line with the endpoints representing "no pain" and "worst pain".

Scleroderma Health Assessment Questionnaire (SHAQ): It is used to evaluate disease activity. ${ }^{[24]}$ It measures the level of impairment caused by Raynaud's phenomenon, digital ulcer, pulmonary and gastrointestinal symptoms as 
well as overall disease activity. ${ }^{[24]}$ VAS is scored between 0 and 3 by multiplying the value by 0.2 . The reliability and validity of Turkish SHAQ have been confirmed in patients with SSc. ${ }^{[25]}$

The Multidimensional Assessment of Fatigue (MAF): It is used for evaluating fatigue and includes 16 items, with a total score ranging between 1 and 50. A high score represents higher fatigue. The Turkish version of MAF is reliable and valid for patients with SSc. ${ }^{[26]}$

Short-Form Health Survey (SF-36): It is used for evaluating HRQL. It includes 36 items consisting of the following subscales: physical functioning, role-physical, bodily pain, general health, vitality, social functioning, role-emotional, and mental health. The total score from all subscales ranges between 0 and 100, with a higher score representing a higher level of HRQoL. ${ }^{[27,28]}$

\section{Translation Process and Face Validity}

The authors of the original scale gave permission for this study. The translation process was carried out following the stages of the guidelines for cross-cultural adaptation of research instruments. ${ }^{[29]}$ Two independent translators who were native Turkish speakers fluent in English, one of the authors of the study and a professional translator, translated the original English text of PHQ-8 into Turkish. These translated texts were then reviewed and compared in terms of the differences and finalized by consensus. Two independent native English speakers who were not familiar with the original scale translated the final version back into English. This back-translation was compared with the original questionnaire for discrepancies between the two texts to determine inconsistencies between the original and the translated versions. These differences were discussed by the translators to achieve a satisfactory level of adaptation to the original scale. The Turkish version of the questionnaire was generated after the translation and back-translation stages of PHQ-8 were produced (Appendix 1). The final version of PHQ-8 was obtained and applied to a pilot sample of 10 patients aged $>18$ years, who were able to understand and read Turkish.

\section{Statistical Analysis}

All statistical analyses of the study were carried out using Statistical Package for Social Sciences (SPSS) version 22.0 for Windows (Chicago, IL, USA). Descriptive statistics were used to summarize demographic characteristics. The normality of the distribution of data was tested by the Kolmogorov-Smirnov test. Non-parametric tests were used for statistical analysis of non-normally-distributed data.
Cronbach's alpha coefficient was used to evaluate internal consistency, with a value greater than 0.70 representing acceptable internal consistency. ${ }^{[29]}$ The corrected item-tototal correlation was also analyzed and a corrected item-total correlation greater than 0.30 was considered acceptable. ${ }^{\text {[30] }}$ PHQ-8 was administered to patients with SSc twice to evaluate test-retest reliability. The presence of a statistically significant difference between the two test sessions for each item and the total score was determined using the sign test. Intraclass correlation coefficient (ICC) values based on the two-way mixed model and absolute agreement were used to evaluate the total score. ${ }^{[31]}$ An ICC value greater than 0.70 was interpreted as acceptable for test-retest reliability. ${ }^{[29]}$

Different correlations between the total scores of the Turkish version of PHQ-8 and HAQ (consisting of HAQDI and VAS), SHAQ, SF-36, and MAF were assessed utilizing hypotheses testing for construct validity. Since most of the data followed a natural order, the Spearman's rank correlation coefficient (rs) was used. A correlation coefficient value of 0 was interpreted as no correlation, 0.1 0.3 weak correlation, 0.4-0.6 moderate correlation, 0.70.9 strong correlation, and 1.0 perfect correlation. ${ }^{[32]}$ The correlation coefficient values obtained from calculations were rounded to one decimal place. The COSMIN checklist was used to support the selection of statistical tests. ${ }^{[21]}$ The level of statistical significance was set at $\mathrm{p} \leq 0.05$.

\section{Results}

A total of 43 patients with SSc (39F, 4M; with a median of 53 years) participating in the testing of aspects of construct validity and reliability. The median disease duration was 10 years and the duration of education was 7.5 years. Table 1 illustrates the demographic and clinical characteristics of patients included in the study.

Of the patients who completed the PHQ-8, 16\% had no significant depressive symptoms, $21 \%$ had mild symptoms, $21 \%$ had moderate symptoms, $19 \%$ had moderately severe symptoms, and $23 \%$ had severe symptoms. The PHQ-8 total score was at a median of 13 .

\section{Linguistic Adjustments}

Most patients completed the questionnaire in less than 5 minutes, with an average evaluation time of 2 minutes. The response rate was $100 \%$ for all items. There were no multiple responses to any of the items. The response options were a bit confusing. The patients did not know what the difference was between "several days" and "more than half of the days". Also, the responders misunderstood items 1 and 5. The 
Table 1. Characteristics of patients with systemic sclerosis (SSC)

\begin{tabular}{|c|c|}
\hline & $\begin{array}{c}\text { Construct validity, } \\
\text { reliability }(n=43)\end{array}$ \\
\hline \multicolumn{2}{|l|}{ Sociodemographic data } \\
\hline Women, n (\%) & $39(91)$ \\
\hline Age in years, median (IQR) & $53(26)$ \\
\hline \multicolumn{2}{|l|}{ Civil status, n (\%) } \\
\hline Married or living together & $36(84)$ \\
\hline Single & $7(16)$ \\
\hline \multicolumn{2}{|l|}{ Level of education, $\mathrm{n}(\%)$} \\
\hline College or university & $9(21)$ \\
\hline High school & $9(21)$ \\
\hline Vocational school or other secondary schools & $11(26)$ \\
\hline Elementary school & $14(33)$ \\
\hline \multicolumn{2}{|l|}{ Professional status, n (\%) } \\
\hline Employed, full- or part-time & $12(28)$ \\
\hline Student or unemployed & $26(60)$ \\
\hline Retired & $5(12)$ \\
\hline \multicolumn{2}{|l|}{ Disease variables } \\
\hline Disease duration in years, median (IQR) & $10(10)$ \\
\hline Limited cutaneous SSc, n (\%) & $27(63)$ \\
\hline Diffuse cutaneous SSc, n (\%) & $16(37)$ \\
\hline Systemic sclerosis sine scleroderma, n (\%) & $10(23)$ \\
\hline \multicolumn{2}{|l|}{ Organ involvement, $\mathrm{n}(\%)$} \\
\hline Skin & $33(77)$ \\
\hline Lung & $28(65)$ \\
\hline Heart & $10(23)$ \\
\hline Kidney & 0 \\
\hline \multicolumn{2}{|l|}{ Comorbidity, n (\%) } \\
\hline Hypertension & $2(5)$ \\
\hline Thromboembolism & $1(2.5)$ \\
\hline Cancer & 0 \\
\hline Diabetes & $1(2.5)$ \\
\hline \multicolumn{2}{|l|}{ ANA positivity, $n$ (\%) } \\
\hline -Anti-SCL-70, n (\%) & $16(37)$ \\
\hline -Anti-centromere, n (\%) & $27(63)$ \\
\hline \multicolumn{2}{|l|}{ Treatment, n (\%) } \\
\hline Calcium channel blockers & $16(37)$ \\
\hline Immunosuppressive treatment & $17(40)$ \\
\hline Biologic agent & $10(23)$ \\
\hline IQR: Interquartile range; SD: Standard deviation & \\
\hline
\end{tabular}

statement "little interest" in item 1 was perceived as "have an interest". Because the present study was conducted during the pandemic period, patients conceived of the statement "poor appetite" in item 5 as secondary to Coronavirus disease-2019.

\section{Aspects of Reliability}

All parameters of PHQ-8 showed a satisfactory internal consistency ranging from 0.735 to 0.845 . The exclusion of item 5 increased Cronbach's alpha value to 0.755 . The
Table 2. Internal consistency of the Turkish version of PHQ-8

\begin{tabular}{lcccc}
\hline $\begin{array}{c}\text { Questionnaire } \\
\text { item }\end{array}$ & $\begin{array}{c}\text { Scale mean } \\
\text { when item } \\
\text { excluded }\end{array}$ & $\begin{array}{c}\text { Scale } \\
\text { variance } \\
\text { when item } \\
\text { excluded }\end{array}$ & $\begin{array}{c}\text { Item-total } \\
\text { correlation }\end{array}$ & $\begin{array}{c}\text { Cronbach's } \\
\text { alpha when } \\
\text { item } \\
\text { excluded }\end{array}$ \\
\hline Item-1 & 24.5 & 130.2 & 0.759 & 0.752 \\
\hline Item-2 & 24.6 & 130.9 & 0.762 & 0.753 \\
\hline Item-3 & 24.8 & 128.2 & 0.735 & 0.748 \\
\hline Item-4 & 24.5 & 126.4 & 0.801 & 0.743 \\
\hline Item-5 & 25.6 & 131.0 & 0.701 & 0.755 \\
\hline Item-6 & 25.0 & 126.6 & 0.845 & 0.743 \\
\hline Item-7 & 25.1 & 128.3 & 0.807 & 0.747 \\
\hline Item-8 & 25.4 & 126.4 & 0.803 & 0.743 \\
\hline All & 13.1 & 34.7 & 0.984 & 0.924 \\
\hline
\end{tabular}

*When question 5 was excluded, the Cronbach's alpha value increased to 0.755 , PHQ: Patient Health Questionnaire-8

Table 3. Stability of the Turkish version of PHQ-8

\begin{tabular}{lccc}
\hline & $\begin{array}{c}\text { Initial score } \\
\text { Mean } \pm \text { SD } \\
(\mathbf{n}=\mathbf{4 3})\end{array}$ & $\begin{array}{c}\text { Retest score } \\
\text { Mean } \pm \mathbf{S D} \\
(\mathbf{n}=\mathbf{4 3})\end{array}$ & ICC (95\% Cl) \\
\hline Item-1 & $2 \pm 0.8$ & $2.3 \pm 0.8$ & $0.970(0.895-0.991)$ \\
\hline Item-2 & $1.9 \pm 0.7$ & $2.2 \pm 0.8$ & $0.939(0.802-0.982)$ \\
\hline Item-3 & $1.9 \pm 0.9$ & $2.0 \pm 0.9$ & $0.925(0.740-0.978)$ \\
\hline Item-4 & $2 \pm 0.9$ & $1.9 \pm 1.0$ & $0.563(0.150-0.851)$ \\
\hline Item-5 & $0.9 \pm 0.8$ & $1.3 \pm 1.2$ & $0.481(0.100-0.817)$ \\
\hline Item-6 & $1.5 \pm 0.8$ & $2.1 \pm 1.1$ & $0.878(0.632-0.963)$ \\
\hline Item-7 & $1.4 \pm 0.8$ & $1.7 \pm 1.05$ & $0.965(0.882-0.990)$ \\
\hline Item-8 & $1.1 \pm 0.9$ & $1.6 \pm 1.0$ & $0.966(0.886-0.990)$ \\
\hline PHQ-8 & $13.6 \pm 6.2$ & $16.09 \pm 6.5$ & $0.947(0.817-0.985)$ \\
score & &
\end{tabular}

ICC: Intraclass correlation coefficient, PHQ-8: Patient health questionnaire-8; SD: Standard deviation, Cl: Confidence interval

Cronbach's alpha value of the whole scale was 0.924 (Table 2 ). The test-retest reliability for all items and scores of the Turkish version of PHQ-8 is presented in Table 3 (ICC $=0.947,95 \%$ confidence interval $0.817-0.985 ; \mathrm{p}<0.001$ ).

\section{Construct Validity}

The PROMs analyzed to determine the construct validity in SSc patients are given in Table 4. There was a moderate correlation between the Turkish version of PHQ-8 and HAQ-DI VAS (pain), MAF (fatigue), and SF-36 subscales (role-physical, bodily pain, vitality, social functioning, and mental health), which supported convergent validity. Moreover, strong correlations were found between the Turkish version of PHQ-8 and HAQ-DI (disability), SHAQ subscales (digital ulcers, Raynaud's phenomenon, lung symptoms, gastrointestinal symptoms, and interferences of overall disease severity with activities of daily living), SF36 subscales (physical functioning, general health, roleemotional) (Table 5). 
Table 4. Scores of the patient-reported outcome measures used to assess construct validity $(n=43)$

\begin{tabular}{lc}
\hline \multicolumn{2}{c}{ Patient-reported outcome measures } \\
\hline HAQ-DI & $0.7(1.75)$ \\
\hline HAQ-DI VAS & $0.5(1)$ \\
\hline -Pain & \\
\hline SHAQ, median (IQR) & $0.18(0.25)$ \\
\hline -Gastrointestinal symptoms & $0.18(0.27)$ \\
\hline -Lung symptoms & $0.21(0.24)$ \\
\hline -Raynaud's phenomenon & $0.11(0.16)$ \\
\hline -Digital ulcers & $0.16(0.27)$ \\
\hline -Overall disease severity & $0.14(0.16)$ \\
\hline SHAQ score 0-3, median (IQR) & $25(20)$ \\
\hline MAF score 1-50, median (IQR) & $45(65)$ \\
\hline RAND-36 score 0-100, median (IQR) & $40(24)$ \\
\hline -Physical functioning & $47(32)$ \\
\hline -Role-physical & $40(27)$ \\
\hline -Bodily pain & $33(66)$ \\
\hline -General health & $55(37)$ \\
\hline -Vitality & $50(75)$ \\
\hline -Social functioning & $44(24)$ \\
\hline -Role-emotional & \\
\hline -Mental health & \\
\hline HAQ-DI: Health assessment questionnaire-disability index, IQR: Interquartile range, \\
MAF: Multidimensional assessment of fatigue, SF-36: short form 36-item health survey, \\
\hline SHAQ: Scleroderma health assessment questionnaire, VAS: Visual analogue scale, \\
\hline
\end{tabular}

\section{Discussion}

This study evaluated the validity and reliability of the Turkish version of PHQ-8 in patients with SSc. There was a correlation between the Turkish version of PHQ-8 and pain, disability, interferences of the disease with activities of daily living, and HRQL. Furthermore, the internal consistency and test-retest reliability values of the questionnaire were satisfactory. Even though the items of the questionnaire were generally relevant and easy to understand, some linguistic revisions had to be made to be better understood by patients with SSc.

Certain items of PHQ-8 are known to involve problems or are related to the somatic symptoms observed in patients with SSc. Our study revealed that the mean scores obtained from item 1 (interest/pleasure), item 2 (depressed/hopeless), item 3 (sleep), and item 4 (tiredness/little energy) were higher than the scores obtained from other items of the Turkish version of PHQ-8. In the literature, the association of these symptoms stated in these four items with each other in patients with SSc has been the subject of numerous studies. Basta et al. ${ }^{[33]}$ reported that fatigue was associated with depression and sleep disorders. The study of Sandusky et al. $^{\left[{ }^{[3]}\right.}$ stated that fatigue increased depressive symptoms. Therefore, sleep problems and fatigue-related items on the PHQ-9 validated in patients with SSc might be associated with somatic symptoms observed in patients with SSc. ${ }^{[35]}$ In
Table 5. Construct validity (correlations) of the Turkish version of patient health questionnaire-8 for SSC patients

\begin{tabular}{|c|c|c|}
\hline \multirow[t]{2}{*}{ Patient-reported outcome measures } & \multicolumn{2}{|c|}{ PHQ-8 } \\
\hline & $r$ & p-value \\
\hline \multicolumn{3}{|c|}{ Disability, pain, and interference of the disease with activities of daily living } \\
\hline HAQ-DI & 0.506 & $<0.001 *$ \\
\hline HAQ-DI VAS & & $<0.001 *$ \\
\hline -Pain & 0.502 & $<0.001 *$ \\
\hline \multicolumn{3}{|l|}{ SHAQ VAS } \\
\hline -Gastrointestinal symptoms & 0.650 & $<0.001 *$ \\
\hline -Lung symptoms & 0.719 & $<0.001 *$ \\
\hline -Raynaud's phenomenon & 0.641 & $<0.001 *$ \\
\hline -Digital ulcers & 0.596 & $<0.001 *$ \\
\hline -Overall disease severity & 0.691 & $<0.001 *$ \\
\hline SHAQ & 0.580 & $<0.001 *$ \\
\hline Fatigue, MAF & 0.773 & $<0.001$ * \\
\hline \multicolumn{3}{|l|}{ Health-related quality of life, RAND-36 } \\
\hline -Physical functioning & 0.801 & $<0.001^{*}$ \\
\hline -Role-physical & 0.756 & $<0.001^{*}$ \\
\hline -Bodily pain & 0.723 & $<0.001 *$ \\
\hline -General health & 0.700 & $<0.001 *$ \\
\hline -Vitality & 0.762 & $<0.001 *$ \\
\hline -Social functioning & 0.676 & $<0.001 *$ \\
\hline -Role-emotional & 0.763 & $<0.001 *$ \\
\hline -Mental health & 0.654 & $<0.001 *$ \\
\hline \multicolumn{3}{|l|}{${ }^{*} p<0.05$ Statistical difference } \\
\hline $\begin{array}{l}\text { rs=Spearman's rank correlation coefficier } \\
\text { questionnaire-disability index, MAF: Multidi } \\
\text { RAND-36: RAND 36-item health survey, SHA } \\
\text { questionnaire, SSc: Systemic sclerosis, VAS: Vis }\end{array}$ & $\begin{array}{l}A Q-D I: \\
\text { nal asse } \\
\text { eroderma } \\
\text { alogue sc }\end{array}$ & $\begin{array}{l}\text { assessment } \\
\text { of fatigue, } \\
\text { assessment }\end{array}$ \\
\hline
\end{tabular}

addition, the fact that fatigue was one of the items with the highest internal consistency among the items of PHQ-8 and having a strong item-total correlation are two important points to take into consideration in our study. Two previous studies also reported a similar result. ${ }^{[12,19]}$

Validation of the different forms of PHQ has been the subject of many studies in the literature. Especially the high internal consistency of PHQ-9 has been demonstrated in two studies. ${ }^{[11,12]}$ Kroenke et al. ${ }^{[13]}$ also studied the reliability and validity of this test on 6,000 patients. They found high reliability based on their study results. Mattson et al. ${ }^{[19]}$, on the other hand, found high internal consistency and reliability of PHQ-8, stating that this value was comparable with the values obtained with PHQ-9. Similar or comparable internal consistency and ICC value of the Turkish version of PHQ-8 to the aforementioned studies support our results. Furthermore, the test-retest procedure showed the highest inter-item difference for item 5 (poor appetite or overeating). Since this study was conducted during the pandemic period, there might be a difference in sense of taste during this period. Also, the study of Mattsson et al. ${ }^{[19]}$ found such a difference in item 3 (staying asleep). 
It is important to determine the correlation or association of the PHQ-8 with other tests to define construct validation. Mattson et al. ${ }^{[19]}$ found a high level of correlation with questionnaires assessing disability, fatigue, and quality of life in patients with SSc. Milette et al. ${ }^{[12]}$ found a significant correlation between PHQ-9 and mental health, physical health, disability, pain, and fatigue. The study of Wafki et al. ${ }^{[36]}$ reported that PHQ-9 was associated with pain and disability. In our study, PHQ-8 correlated with questionnaires assessing fatigue, disability, and quality of life. This indicates that depressive or somatic symptoms observed in patients with SSc impair the quality of life, causing limitations in activities of daily living.

\section{Study Limitations}

Our study has three important potential limits. First, another scale that assesses depression was not used. However, no test assessing depression has been validated in Turkish SSc patients. In addition, PHQ-8 was found to correlate with mental health, one of the components of SF36. Secondly, the correlation between comorbidities and PHQ-8 was not determined because some comorbidities are known to increase depressive symptoms and cause disability. Third, and perhaps the most important limitation of our study is the small sample size. Therefore, there is a need for large and multicenter studies to verify our study results.

\section{Conclusion}

PHQ-8 is a reliable and valid test in Turkish SSc patients. It was also found to be critical in detecting depressive symptoms in patients with SSc.

\section{Ethic}

Ethics Committee Approval: The approval for the study was obtained from the local ethics committee (numbered 10.150.1.90, date: 25.02.2021).

Informed Consent: Their written informed consent was obtained.

Peer-review: Externally peer-reviewed.

\section{Authorship Contributions}

Concept: S.K., U.K., H.A., V.Ç., Design: S.K., Data Collection or Processing: S.K., U.K., V.Ç., Analysis or Interpretation: S.K., U.K., H.A., V.Ç., Literature Search: U.K., H.A., V.Ç., Writing: S.K.

Conflict of Interest: No conflict of interest was declared by the authors.

Financial Disclosure: The authors declared that this study received no financial support.

\section{References}

1. Furue M, Mitoma C, Mitoma H, et al. Pathogenesis of systemic sclerosis-current conceptand emerging treatments. Immunol Res 2017;65:790-7.

2. Hussein H, Lee P, Chau C, Johnson SR. The effect of male sex on survival in systemic sclerosis. J Rheumatol 2014;41:2193-200.

3. Orlandi M, Barsotti S, Lepri G, et al. One year in review 2018: systemic sclerosis. Clin Exp Rheumatol 2018;113:3-23.

4. Leon L, Abasolo L, Redondo M, et al. Negative affect in systemicsclerosis. Rheumatol Int 2014;34:597-604.

5. Panopoulos S, Tektonidou M, Drosos AA, et al. Prevalence of comorbidities insystemic sclerosis versus rheumatoid arthritis: a comparative, multicenter, matched-cohort study. Arthritis Res Ther 2018;20:267.

6. Thombs BD, Van Lankveld W, Bassel M, et al. Psychological health and well-being insystemic sclerosis: state of the science and consensus research agenda. Arthritis Care Res (Hoboken) 2010;62:1181-9.

7. Thombs BD, Kwakkenbos L, Levis AW, Benedetti A. Addressing overestimation of the prevalence of depression basedon self-report screening questionnaires. CMAJ 2018;190:E44-E49.

8. Nguyen C, Ranque B, Baubet T, et al; Groupe Français de Recherche sur la Sclérodermie. Clinical, functional and health-related quality of life correlates of clinically significant symptoms of anxiety and depression in patients with systemic sclerosis: a cross-sectional survey. PLoS One 2014;9:e90484.

9. March C, Huscher D, Preis E, et al. Prevalence, risk factors and assessment of depressive symptoms in patients with systemic sclerosis. Arch Rheumatol 2019;34:253-261.

10. Brunger M, Spyra K. Prevalence of comorbid depressive symptoms in rehabilitation: a cross-indication, nationwideobservational study. J Rehabil Med 2016;48:903-8.

11. Arthurs E, Steele RJ, Hudson M, Baron M, Thombs BD; (CSRG) Canadian Scleroderma Research Group. Are scores on English and French versions of the PHQ-9 comparable? An assessment of differential item functioning. PLoS One 2012;7:e52028.

12. Milette K, Hudson M, Baron M, Thombs BD; Canadian Scleroderma Research Group. Comparison of the PHQ-9 and CES-D depression scales in systemic sclerosis: internal consistency reliability, convergent validity and clinical correlates. Rheumatology (Oxford) 2010;49:789-96.

13. Kroenke K, Spitzer RL, Williams JB, Lowe B. The patient health questionnaire somatic, anxiety, and depressive symptomscales: a systematic review. Gen Hosp Psychiatry 2010;32:345-59.

14. Palfreyman S. Patient-reported outcome measures and how they are used. Nurs Older People.2011;23:31-6.

15. Razykov I, Hudson M, Baron M, Thombs BD; Canadian Scleroderma Research Group. Utility of the Patient Health Questionnaire-9 to assess suicide risk in patients with systemic sclerosis. Arthritis Care Res (Hoboken) 2013;65:753-8.

16. Adler M, Hetta J, Isacsson G, Brodin U. An item response theory evaluation of three depression assessment instruments ina clinical sample. BMC Med Res Methodol 2012;12:84.

17. Hansson M, Chotai J, Nordstöm A, Bodlund O. Comparison of two self-rating scales to detect depression: HADS and PHQ-9. Br J Gen Pract 2009;59:283-8.

18. Reich H, Rief W, Brähler E, Mewes R. Cross-cultural validation of the German and Turkish versions of the PHQ-9: an IRT approach. BMC Psychol 2018;6:26.

19. Mattsson M, Sandqvist G, Hesselstrand R, Nordin A, Boström C. Validity and reliability of the Patient Health Questionnaire-8 
in Swedish for individuals with systemic sclerosis. Rheumatol Int 2020;40:1675-87.

20. Van den Hoogen F, Khanna D, Fransen J, et al. 2013 classification criteria for systemicsclerosis: an American College of Rheumatology/European League against rheumatism collaborative initiative. Arthritis Rheum 2013;65:2737-47.

21. Mokkink LB, de Vet HCW, Prinsen CAC, et al. COSMIN Risk of Bias checklist for systematic reviews of Patient-Reported Outcome Measures. Qual Life Res 2018;27:1171-9.

22. Marx RG, Menezes A, Horovitz L, Jones EC, Warren RF. A comparison of two time intervals for test-retest reliability of health status instruments. J Clin Epidemiol 2003;56:730-5.

23. Fries JF, Spitz P, Kraines RG, Holman HR. Measurement of patient outcome in arthritis. Arthritis Rheum 1980;23:137-45.

24. Steen VD, Medsger TA. The value of the Health Assessment Questionnaire and special patient-generated scales to demonstrate change in systemic sclerosis patients over time. Arthritis Rheum 1997;40:1984-91.

25. Hesselstrand R, Nilsson JA, Sandqvist G. Psychometric properties of the Swedish version of the Scleroderma Health Assessment Questionnaire and the Cochin Hand Function Scale in patients with systemic sclerosis. Scand J Rheumatol 2013;42:317-24.

26. Sandqvist G, Archenholtz B, Scheja A, Hesselstrand R. The Swedish version of the Multidimensional Assessment of Fatigue (MAF) in systemic sclerosis: reproducibility and correlations to other fatigue instruments. Scand J Rheumatol 2011;40:493-4.

27. Orwelius L, Nilsson M, Nilsson E, et al. The Swedish RAND-36 Health Survey - reliability and responsiveness assessed in patient populations using Svensson's method for paired ordinal data. J Patient Rep Outcomes 2017;2:4.
28. Danieli E, Airo P, Bettoni L, et al. Health-related quality of life measured by theShort Form 36 (SF-36) in systemic sclerosis: correlations with indexes of disease activity and severity, disability, and depressivesymptoms. Clin Rheumatol 2005;24:48-54.

29. Prinsen CAC, Mokkink LB, Bouter LM, et al. COSMIN guideline for systematic reviews of patient-reported outcome measures. Qual Life Res 2018;27:1147-57.

30. Ferketich S. Focus on psychometrics. Aspects of item analysis. Res Nurs Health 1991;14:165-8.

31. Koo TK, Li MY. A guideline of selecting and reporting intraclass correlation coefficients for reliability research. J Chiropr Med 2016;15:155-63.

32. Akoglu H. User's guide to correlation coefficients. Turk J Emerg Med 2018;18:91-3.

33. Basta F, Afeltra A, Margiotta DPE. Fatigue in systemic sclerosis: a systematic review. Clin Exp Rheumatol 2018;36:150-60.

34. Sandusky SB, McGuire L, Smith MT, Wigley FM, Haythornthwaite JA. Fatigue: an overlooked determinant of physical function in scleroderma. Rheumatology (Oxford) 2009;48:165-9.

35. Leavens A, Patten SB, Hudson M, Baron M, Thombs BD; Canadian Scleroderma Research Group. Influence of somaticsymptoms on Patient Health Questionnaire-9 depression scores among patients with systemic sclerosis compared to a healthy general population sample. Arthritis Care Res (Hoboken) 2012;64:1195-201.

36. Wafki F, Amine B, Ibn Yacoub Y, et al. Depression among the Moroccan systemic sclerosis. Clin Rheumatol 2012;31:73-7.

\section{Appendix 1.}

Hasta Sağlığı Anketi (PHQ-8)

Geçtiğimiz 2 hafta içinde așağıdaki sorunlardan herhangi biri sizi ne sıklıkla rahatsız etti?

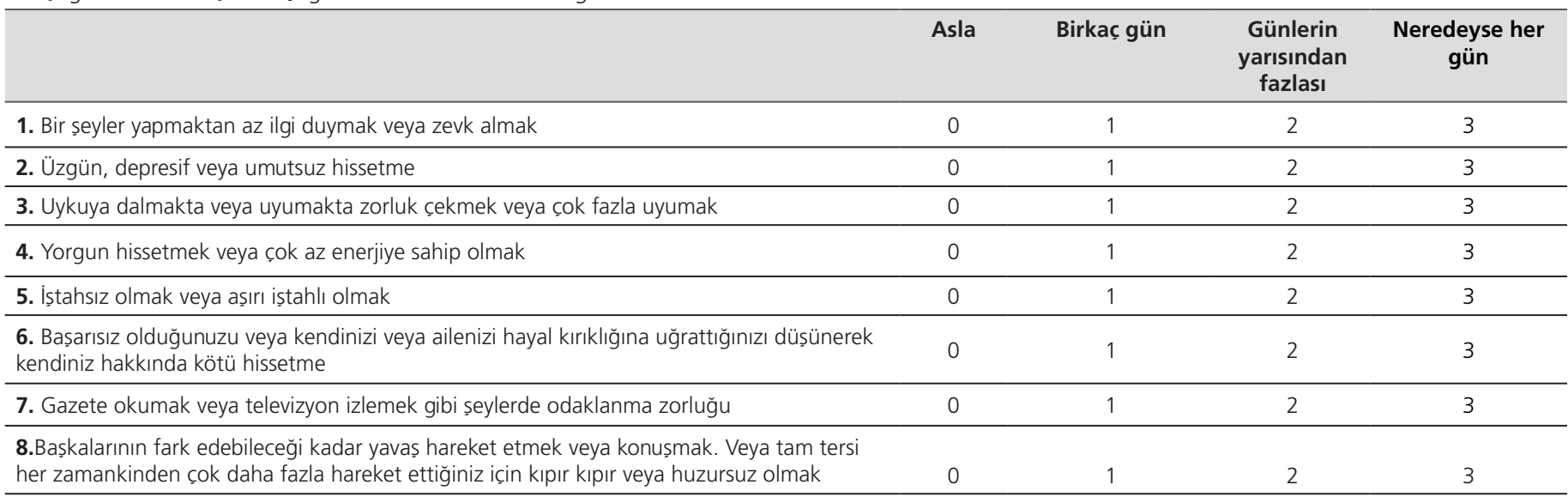

\begin{tabular}{|cc|}
\hline+ & + \\
\hline & Toplam: \\
\hline
\end{tabular}

\begin{tabular}{ll}
\hline & Hiç zor değil __ \\
$\begin{array}{l}\text { Herhangi bir sorunu kontrol ettiyseniz, bu sorunlar ișinizi yapmanızı, evdeki ișlerinizi halletmenizi veya diğer insanlarla } \\
\text { iyi geçinmenizi ne kadar zorlaștırdı? zor }\end{array}$ & Çok zor__ Son derece zor __ \\
\hline
\end{tabular}

